\title{
Factors of Influencing Health Workers in Providing Early Complementary Breastfeeding in dr. Iskak Hospital Tulungagung
}

Poppy Farasari ${ }^{1}$, Indasah ${ }^{2}$, Sentot Imam S. ${ }^{2}$

\footnotetext{
${ }^{1}$ Magister of Health Study Program of STIKes Surya Mitra Husada Kediri

${ }^{2}$ Lecturer of STIKes Surya Mitra Husada Kediri popfarsar5@gmail.com
}

Received : March 13, 2018

Accepted : May 08, 2018

Published : May 11, 2018

\section{ABSTRACT}

Breast milk is the best food God creates for newborns. Artificial feeds for infants mixed using today's technology, were not able to match the benefits of breast milk. The purpose of the study was to analyze Factors affecting the Health Worker in giving the Early Breastfeeding in dr. Iskak Hospital Tulungagung. The research design used in the research is Analytical Observation. The population is health workers who have babies 6-12 months of age. The sample size was 67 respondents using Cluster Random Sampling technique. Independent variable of research is knowledge, distance, and family support. The dependent variable of the research is the early feeding of breast milk supplements. Data were collected by using questionnaire, then the data were analyzed by using logistic regression. The results showed that most have residence distance to the workplace as far as $3 \mathrm{KM}$ as many as 44 respondents $(65.7 \%)$, most have good knowledge as many as 64 respondents $(95.5 \%)$, most have high family support as much as 45 respondents (67.2\%), most respondents gave ASI without MP-ASI as much as 42 respondents $(62,7 \%)$. Statistical test results that Overall Statistics with a significance value of (p) 0,000 which means that there are variables that affect the administration of MPASI and variable most affect family support with a value of (p) of 0.000 . The conclusion of this study is family support affects in health workers in providing early breastfeeding in dr. Iskak Hospital Tulungagung.

Keywords : Early complementary breastfeeding, Family support, Labor.

Copyright $@ 2018$ STIKes Surya Mitra Husada

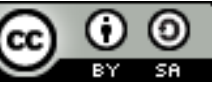

This is an open-acces article distributed under the terms of the Creative Commons Attribution-ShareAlike 4.0 International License. 


\section{INTRODUCTION}

Breast milk is the best food of God's creation is intended for newborns. Imitation foods for infants who are mixed using current technology, it can not match the advantages of breast milk. Because breast milk, has the highest nutritional value compared to baby food made by man or milk derived from animals, such as cow's milk, buffalo, or goat (Suhardjo, 2012). The quality of human resources is determined by the adequacy of nutrients derived from food consumed from infancy. In the infancy of growth and development takes place very rapidly and brain development has reached $70 \%$ (Roesli, 2012).

Breast milk is the optimal nutrition for infants and is an ideal food for your baby's digestive system is growing. In addition, breast milk provides some protection against certain infectious diseases that potentially affects infants in the first weeks of life (MIMS Midwives, 2012). Exclusive breastfeeding according to WHO (World Health Organization) is breastfeeding without additional other fluids either formula, water, juice, or other food additives. Solids (weaning food) is the provision of complementary foods in addition to breast milk when the baby is 6 months old. ASI only provide half or more nutritional needs of infants at the age of 6-12 months. Entering 12-14 months, breast milk provides only one-third of their nutritional needs. For that baby needs to get solids to meet the nutritional needs of the body (Roesli, 2013).

WHO / UNICEF recommend four important things to note are: first, to provide breast milk to the infant immediately within 30 minutes after the baby is born; second, to provide breast milk (ASI) only or exclusive breastfeeding from birth until the baby is 6 months old; Third, provide supplementary food, milk (MP-ASI) since infants aged 6-24 months; and four continue breastfeeding until the child is aged 24 months or more. Breastfeeding should be easily digestible, should be tailored to the age and needs of the baby and breastfeeding should contain sufficient calories and micronutrients. Gradually, the baby can menyicip other liquid menu, then soft, and continues to roughage. (Nutrition Department of Health, 2014).

Health workers who also serves as the capital has its own challenges in breastfeeding exclusively or not provide early complementary feeding. Umar research results (2014) determinant factor in the behavior of mothers who work and efforts were not giving breastfeeding early ie promotion of health and family support. Lucky research results, (2008) with the title of exclusive breastfeeding mother working experience showed that the practice of exclusive breastfeeding is influenced by the perception and understanding and knowledge about the benefits of breast-feeding mothers, preservation of breastfeeding and how to order the production of breast milk remains well. Mom worked much of the time outside the home and choose to use formula milk because they are more profitable. Mom worked as health professionals have the knowledge and the assurance in the granting of exclusive breastfeeding. Mothers work habits and even the mother is in hospital health workers in infant feeding is not appropriate, one of which is the provision of food too early. Feeding too early can cause digestive problems such as diarrhea, vomiting, and constipation (Cott, 2013). Infant feeding in Indonesia are still many who do not according to age, especially in rural areas.

Umar research results (2014) with the title of the determinant factors in the exclusive breastfeeding in the city of Pare Pare Working Mom Working mothers found that $80.4 \%$ give early breastfeeding her baby. Suryani research results (2016) with the title Determinants of success of exclusive breastfeeding in the mother working in Puskesmas Umbrella Sekaki obtained the factors that influence the success of the granting of exclusive breastfeeding at a mother who worked as knowledge, motvasi, husband support, and the support of health professionals. The results showed that in rural communities in Indonesia generally give bananas (57.3\%) to the baby before the age of 4 months (Research, 2013). Based on data from Demographic and Health Survey (Indonesia Demographic and Health Survey), in 2014 some babies already get food / drinks weaning early, 36\% of infants less than 2 months old receive complementary foods consisting of water $(4.1 \%)$, other liquids $(2.7 \%)$, non-breastfed milk $(16.3 \%)$ and solid foods or creamed $(21.1 \%)$, given solid food infant aged 2-3 months. Of East Java Health Office data mentioned during the year 2012 of a total of 459021 babies 
were examined contained 164896 babies who were given breastfeeding before the age of 6 months.

It is known that feeding too early breastfeeding by the mother worked in children can lead to digestive disorders in infants such as diarrhea, constipation, vomiting, and allergies. Besides, it will affect the level of intelligence of children after the age of adulthood as trigger the disease of obesity, hypertension, and coronary heart disease (Nadesul, 2014). Many factors are background for the emergence of behavioral problems giving breastfeeding Health workers therefore can not provide exclusive breastfeeding or giving the PM-breastfeeding early. Health personnel have a good knowledge related to health but there masi health workers who have not been able to provide milk for babies aged 0-6 months. The theory is closely related to the behavior associated with the provision of breastfeeding. To reduce the provision of early complementary feeding to babies, the government has made the class agenda pregnant women who regularly held every month by midwives, followed by pregnant women and postpartum visits conducted to provide CIE on mother and baby. Based on the above background there any researcher interested in examining the factors that influence the health personnel in providing breastfeeding Early in RSUD dr. Iskak Tulungagung

\section{METHOD}

The research design used in the study Analytical observations. The population is a health worker who had infants aged 6-12 months. The sample size was 67 respondents usingtechnique. simple random samplingIndependent Variable research is knowledge, distance, and family support. The dependent variable of the study is supplementary feeding breast milk at an early stage. Data was collected using aquestionnaire, then the data were analyzed by using logistic regression

\section{RESULTS}

The results showed the characteristics of respondents and the data displayed on the frequency distribution table below:

Table 1. Characteristics Age Distribution of Respondents in RSUD dr. Iskak Tulungagung (n $=67)$

\begin{tabular}{cccc}
\hline No. & Age Respondents & Frequency & Percentage \\
\hline 1 & $20-30$ years & 20 & 29.9 \\
\hline 2 & $31-40$ years & 47 & 70.1 \\
\hline & Total & $\mathbf{6 7}$ & $\mathbf{1 0 0}$ \\
\hline
\end{tabular}

The results showed that the number of respondents was 67 and most of the respondents aged 31-40 years as many as 47 respondents (70.1\%) were aged 20-30 years and as many as 20 respondents $(29.9 \%)$.

Table 2. Distribution Characteristics of Baby age Respondents in RSUD dr. Iskak Tulungagung $(\mathrm{n}=67)$.

\begin{tabular}{clcc}
\hline No. & Age Babies Respondents & Frequency & Percentage \\
\hline 1 & $6-7$ months & 14 & 20.9 \\
\hline 2 & $8-9$ months & 26 & 38.8 \\
\hline 3 & $10-12$ months & 27 & 40.3 \\
\hline & Total & $\mathbf{6 7}$ & $\mathbf{1 0 0}$ \\
\hline
\end{tabular}


The results showed that the number of respondents by 67 respondents, mostly aged baby respondents $10-12$ months as many as 27 respondents (40.3\%) and the least was 6-7 months a total of 14 respondents $(20.9 \%)$.

Table 3 Distribution Characteristics of Respondents Education in RSUD dr. Iskak Tulungagung $(\mathrm{n}=67)$

\begin{tabular}{|c|c|c|c|}
\hline No. & Education & Frequency & Percentage \\
\hline 1 & D3 & 21 & 31.3 \\
\hline 2 & $\mathrm{~S} 1$ & 33 & 49.3 \\
\hline 3 & Doctors & 11 & 16.4 \\
\hline 4 & Specialist & 2 & 3.0 \\
\hline & Total & 67 & 100 \\
\hline
\end{tabular}

The results showed that the number of respondents by 67 respondents, mostly educated respondents $\mathrm{S} 1$ as many as 33 respondents $(49.3 \%)$ and the least educated specialists as much as 2 respondents $(3 \%)$.

Table 4 Distribution Characteristics Distance residence to workplace Respondents in RSUD dr. Iskak Tulungagung $(\mathrm{n}=67)$.

\begin{tabular}{cccc}
\hline No. & $\begin{array}{c}\text { Distance residence } \\
\text { on the workplace }(\mathbf{K m})\end{array}$ & Frequency & Percentage \\
\hline 1 & 1 & 12 & 17,9 \\
\hline 2 & 2 & 1 & 1,5 \\
\hline 3 & 3 & 44 & 65,7 \\
\hline 4 & 4 & 2 & 3,0 \\
\hline 5 & 6 & 4 & 6,0 \\
\hline 6 & 7 & 1 & 1,5 \\
\hline 7 & 10 & 2 & 3,0 \\
\hline 8 & 12 & 1 & 1,5 \\
\hline & Total & $\mathbf{6 7}$ & $\mathbf{1 0 0}$ \\
\hline & & & Frequency \\
\hline No. & Distance residence & & \\
\hline 1 & on the workplace $(\mathbf{K m})$ & 12 & 17,9 \\
\hline 2 & 1 & 1 & 1,5 \\
\hline 3 & 2 & 44 & 65,7 \\
\hline 4 & 3 & 2 & 3,0 \\
\hline 5 & 4 & 4 & 6,0 \\
\hline 6 & 6 & 1 & 1,5 \\
\hline 7 & 7 & 2 & 3,0 \\
\hline 8 & 10 & 1 & 1,5 \\
\hline & 12 & $\mathbf{6 7}$ & $\mathbf{1 0 0}$ \\
\hline & Total & &
\end{tabular}

The results showed that the number of respondents by 67 respondents, most have a distance a place to stay on the workplace as far as $3 \mathrm{KM}$ as many as 44 respondents $(65.7 \%)$ and the least have a distance a place to stay on the workplace as far as 2,7 and $12 \mathrm{Km}$ respectively of one respondent $(1.5 \%)$. 
Table 5 Distribution of Knowledge Characteristics of Respondents in RSUD dr. Iskak Tulungagung $(\mathrm{n}=67)$

\begin{tabular}{ccccc}
\hline No. & & Knowledge & Frequency & Percentage \\
\hline 1 & Enough & 3 & 4.5 \\
\hline 2 & Good & & 64 & 95.5 \\
\hline & Total & $\mathbf{6 7}$ & $\mathbf{1 0 0}$ \\
\hline
\end{tabular}

The results showed that the number of respondents by 67 respondents, most have a good knowledge of as many as 64 respondents $(95.5 \%)$ and the least have many as three respondents $(4.5 \%)$.

Table 6 Distribution Characteristics of Family Support Respondents in RSUD dr. Iskak Tulungagung $(\mathrm{n}=67)$.

\begin{tabular}{cccc}
\hline No. & Family Support & Frequency & Percentage \\
\hline 1 & Medium & 22 & 32.8 \\
\hline 2 & High & 45 & 67.2 \\
\hline \multicolumn{2}{r}{ Total } & $\mathbf{6 7}$ & $\mathbf{1 0 0}$ \\
\hline
\end{tabular}

The results showed that the number of respondents by 67 respondents, most have a high family support as many as 45 respondents (67.2\%) and the least family support that are as much as 22 respondents $(32.8 \%)$.

Table 7 Distribution Characteristics of Respondents Giving breastfeeding in RSUD dr. Iskak Tulungagung $(\mathrm{n}=67)$

\begin{tabular}{clcc}
\hline No. & \multicolumn{1}{c}{ Provision MP-ASI } & Frequency & Percentage \\
\hline 1 & ASI MPearly & 25 & 37.3 \\
\hline 2 & $\begin{array}{l}\text { Without complementary } \\
\text { feeding }\end{array}$ & 42 & 62.7 \\
\hline \multicolumn{2}{c}{ Total } & $\mathbf{6 7}$ & $\mathbf{1 0 0}$ \\
\hline
\end{tabular}

The results showed that the number of respondents by 67 respondents, most respondents give milk without MP -ASI as many as 42 respondents $(62.7 \%)$ and the least provide early complementary feeding as many as 25 respondents $(37.3 \%)$.

Table 8 Results of logistic regression

\begin{tabular}{|c|c|c|c|c|c|c|}
\hline & $\mathrm{B}$ & $\mathrm{SE}$ & Wald & $\mathrm{df}$ & Sig. & $\operatorname{Exp}(\mathrm{B})$ \\
\hline \multirow[t]{2}{*}{ Step 0 Constant, } & & 519,253 & 4.218 & 1 & 040 & 1.680 \\
\hline & & & & Score & df & Score \\
\hline \multirow[t]{4}{*}{ Step 0} & Variables & Distance & & 3.472 & & 1062 \\
\hline & & Knowledge & & 1.157 & 1, & 282 \\
\hline & & Dukungan $\mathrm{k}$ & & & 1 & $27.737,000$ \\
\hline & Statistic & verall & & 30.230 & 3 & 000 \\
\hline
\end{tabular}

Statistical test on this new study used regression, logistics the test results listed in the table above. Statistical test results in this study show that in variables in the equation obtained indigo slope or coefficients Beta (B) of the constants (Exp (B) of 1,680, the value of significance $p$ value of wald test amounted to 0,040 , which means that each variable influence partially. Value B is identical to the beta coefficient on ordinary least squares (OLS) with $\operatorname{Exp}(0.519)=1.680$, which means that the independent variable has a positive effect of $168 \%$ to the dependent variable. Statistical test results obtained total df 3 (two) which tells us the number of independent variables exist 3. 
Statistical test results the next stage in the second table shows that $\mathrm{p}<\mathrm{a}$ with a value of $<0.05$, as seen in the Overall statistics with significance value of (p) 0.000 , which means that there are variables that affect the administration of MP -ASI. When viewed value (p) for each independent variable has a value that is variable distance (p) of 0,062 , knowledge variable has a value of (p) is 0,282 , and family support variable has a value of (p) of 0.000 .

\section{DISCUSSION}

Based on the research results of statistical tests in this study showed that in the equationvariablesobtained indigoslope or Beta coefficient (B) of the constants (Exp (B) of 1,680 , the value of significance $p$ value of wald test amounted to 0,040 , which means that each variable give partial effect. Value B is identical to the beta coefficient on ordinary least squares $(\mathrm{OLS})$ with $\operatorname{Exp}(0.519)=1.680$, which means that the independent variable had a positive effect of $168 \%$ to the dependent variable. the statistical test result is obtained the total df 3 (two), which tells us the number of independent variables exist 3. Statistical test results showed that $\mathrm{p}<\mathrm{a}$ with a value of $<0.05$, as seen in the Overall statistics with significance value of (p) 0.000 , which means that there are variables that affect the administration of MP ASI. When viewed value (p) for each independent variable has a value that is variable distance (p) of 0,062, knowledge variable has a value of (p) se 0,282 large and variable family support has a value of (p) of 0.000 .

Complementary foods are foods given to babies / children in addition to breastmilk to meet their nutritional needs (MOH, 2014). Breastfeeding is given to children aged 6 months to 24 months, because at that time the milk production continues to drop so that the supply of nutrients from breast milk no longer meets the nutritional needs of children increased so that the provision in the form of complementary foods is highly recommended (WHO, 1993), Breastfeeding is a food or beverage that contains nutrients, given to infants or children aged 6-24 months in order to meet the nutritional needs apart from breastfeeding ( $\mathrm{MOH}, 2006)$. Breastfeeding is a food transition from breastfeeding to family foods. The introduction and provision of breastfeeding should be done gradually form and amount. It is intended to adjust the tool's ability to receive the baby's digestive breastfeeding (MOH, 2004). After a 6-monthold baby gradually need complementary foods such as fruit juice, or fruit, rice team, soft foods and eventually the food mushy. The purpose of the provision of complementary foods is $(\mathrm{MOH}, 2014)$. Supplementary food for babies is supposed to produce energy as high as possible, contain at least $360 \mathrm{kcal}$ per 100 grams of material. Supplementary food for infants should be nutrient dense and contain crude fiber and other materials that are difficult to digest as minimal as possible, since coarse fibers are too many numbers will interfere with digestion (Deddy, 2012).

Based on the results of each variable give partial effect seen in overalls Statistics with significance value of (p) 0.000 , which means that there are variables that affect the administration of breastfeeding. When seen the value of $(p)$ for each independent variable has a value that is variable distance (p) of 0,062 , knowledge variable has a value of (p) of 0,282 , and family support variable has a value of $(\mathrm{p})$ of 0.000 . Based on these results it was found that the most influential variable is predominantly family support. A complete family support in give information, help, support and motivation to improve breastfeeding baby early at the age of 0-6 months. Breastfeeding is important for baby's accordance expressed by Hubertin, 2014 that breast milk is the food intake that meets all the elements of the baby's needs, either physical, or spiritual psikologisocial. Breastmilk include nutrients, hormones, immune factors of growth, anti-allergic and anti-inflammatory. Nutrients in breast milk include nearly 200 elements of a food substance. At the age of six months, the baby's digestive strong start. Giving complementary foods must be after the age of six months, because if given too early will reduce the consumption of breast milk and infant can experience indigestion or diarrhea. Conversely if the supplementary food is given too late will result in malnourished children in the event in a long time. 


\section{REFERENCES}

Alimul, A. (2013). Research Keperawaan And Engineering Scientific Writing. Medika Salemba. Jakarta.

Arifin, B. (2014). Food In New Order. Logistics Agency. Jakarta.

Arikunto, S. (2013). Research Procedure A Practical Approach. Rineka Cipta. Jakarta.

Asep, H. (2013). Quantitative Business Research Paradigm. Grasindo. Jakarta.

Badriul, H. (2014). Early Initiation of Breast feeding. Mother library. Jakarta.

Cott, PW. (2013). Series Culture Kids, Healthy Food For Babies and Toddlers. Dian Rakyat. Jakarta.

Deddy. (1994). Problems exclusive breastfeeding Program and Complementary feeding, Jakarta.

Efendi, F. (2012). Community Health Nursing Theory and Practice in Nursing. Medika Salemba. Jakarta.

Elly, S. (2015). Make Healthy Food Baby. Medical Association Board of Indonesia. Jakarta.

Green, L.W., \& Kreuter, M.W. (1993). Health Education Planning An Educational and Environmental Approach, Second Edition Mayfield Publishing. California.

Hidayat, \& Aziz, A. (2012). Midwifery Research Methods: Data Analysis Techniques. Medika Salemba. Jakarta.

Jusup, L. (2013). Enhancing Food Body Endurance Infants and Toddlers. Gramedia. Jakarta.

MIMS. (2012). Enjoy Your Pregnancy Moms. PT Agro Media Book. Jakarta.

MOH. (2012). Nutrition in Figures until2002. The Directorate General of Community Nutrition. Jakarta.

Muhilal. (2012). Recommended Nutrition Adequacy Score. Nutrition Indonesia. Volume XVII No. 1-2 Persagi. Jakarta.

Nadesul, S.H. (2015). Healthy Food For Babies. Puspa Swara. Jakarta.

Notoatmodjo, S. (2013). Introduction to Health Education and Behavioral Sciences, PT Rineka. Jakarta.

Novak \& Broom, (2012). Studyguide For Maternal and Child Health Nursing.

Profit. (2008). Study Phenomenology: Exclusive Breastfeeding Mothers Work experience in Kendal, Central Javaregion. Journal Media Nurses Vol 2 No May 1, 2008 Page 1-13.

Rahayu, P. (2015). In the College of Nursing. Publisher Andi. Jakarta.

Research and Development. (2013). Research and development Center for Nutrition and Food. Jakarta. 
Roesli, U. (2012). Know Your exclusive breast feeding. Poster Agriwidya. Jakarta.

Sarbini \& Hidayati. (2008). The relationship between family income and education level of mother with exclusive breast feeding in the District Municipality of Surakarta Jebres. Kesehatal journal, ISSN 1979-7621, December 2008 Page 115-122.

Suhardjo, (2012). Food and Nutrition Plan. Earth Literacy. Jakarta.

Susanti. (2011). The role of breast-feeding mothers who work in the Share Exclusive breast feeding baby. Egalita Journal of Gender Equality and Justice Vol VI No June 2, 2011 Page 165-176.

The Directorate General of Community Nutrition. Jakarta. (2015). General Guidelines for Complementary Feeding breast milk (MP - ASI) Local2006.The Directorate General of Public Health. Jakarta.

WHO. (1993). Feeding, Interpretation: Lilian J, EGC, Jakarta and Management Guidelines for Food Companion BMS (MP - ASI )2004. 2014. Distribution 